\title{
Factors influencing interrill erosion from semiarid slopes in New Mexico
}

\author{
BRADFORD P. WLCOX AND M. KARL WOOD
}

\begin{abstract}
This rainfall simulation study evaluates the effects of slope, vegetation, rock, and soll characteristics on interrill erosion of semiarid slopes of the Guadalupe Mountains of New Mexico. A single-nozzle rainfall simulator applied rainfall on slope gradients ranging from 0-70\%. Multicollinearity in the data was corrected for by using partial correlation analysis. Interrill erosion was most infuenced by slope gradient; however, the effect of slope gradient was modified by other factors, particularly vegetation. Vegetation greatly lessened interrill erosion, especially during the initial stages of runofi. Shrubs decreased interrill erosion more than did either grasses, litter, or forbs. Sediment concentration was greater from erosion pavements than from well-vegetated plots. Increases in rock cover, however, without corresponding decreases in vegetal cover, afforded additional protection against interrill erosion. Soil texture and soil depth were the most influential soil factors, particularly on steep slopes.
\end{abstract}

Key Words: rainfall simulation, range hydrology, hillslope hydrology, soil erosion, watershed management

Sediment load of rivers in the western United States is derived mainly from semiarid watersheds (Branson et al. 1981). An understanding of factors that influence erosion on semiarid watersheds is vital to minimizing sediment load of rivers, and to maintaining health and productivity of rangelands. In semiarid environments (if gully erosion is not active), sheet erosion is the source of most sediment, most of which is carried out of the basin rather than being deposited locally (Leopold et al. 1966).

Vegetation is a major factor determining amount of soil erosion by water. Vegetation protects the soil surface from raindrop impact, decreases the velocity of runoff, encourages soil aggregation, binds the soil with roots, and reduces soil compaction (Selby 1982, Carson and Kirkby 1972). As a rule of thumb, vegetal cover of less than $8 \%$ does not control erosion, and vegetal cover above $70 \%$ provides little additional protection; changes in vegetal cover between 8 and $70 \%$ greatly affect erosion (Schumm 1977).

Soil characteristics such as bulk density, texture, structure, and moisture conditions, by virtue of their effect on amount of surface runoff, also influence soil erosion. Soil erodibility under a given set of topographic and runoff conditions depends to a large degree on aggregate stability (Young and Onstad 1982, De Ploey and Poesen 1985). Soil aggregate strength, in turn, is generally correlated with the amount of clay, type of clay, organic matter content, and aggregate size (Young and Onstad 1982). Soil erodibility also increases as percent composition of silt-sized particles increase (Wischmeier and Mannering 1969).

Many slopes in semiarid watersheds are covered with a coarsegrained surface layer of erosion pavement, produced by removal of finer grained particles by overland flow. Rocks dissipate raindrop

\footnotetext{
Authors are hydrologist, USDA-Agricultural Research Service, Northwest Watershed Research Center, 270 South Orchard, Boise. 83705; and professor, Department of Animal and Range Sciences, New Mexico State University, Las Cruces 88003.

New Mexico Agricultural Experiment Station Journal Article No. 1390. The authors gratefully acknowledge assistance in the field by John Phillips and Chris Gannon. The senior author also thanks John Pitlick and 2 anonymous reviewers for constructively reviewing this manuscript.

Manuscript accepted 24 August 1988.
}

energy, reduce the area of erodible surface, and slow the velocity of runoff (Simanton et al. 1984).

One of the most important factors influencing hillslope erosion is slope gradient (Craddock and Pearse 1938, Hadley and Schumm 1961, Meeuwig 1970). The relationship between erosion and slope gradient has been expressed as:

$$
\mathbf{E}=\mathbf{a} \mathbf{S}^{\mathbf{b}}
$$

where $\mathrm{E}$ is erosion, $\mathrm{S}$ is slope gradient (\%), and $\mathrm{a}$ and $\mathrm{b}$ are fitted parameters (Zingg 1940). On agricultural lands, where most plot studies investigating the effect of slope steepness have been carried out, b has ranged from 1.35-2 (Selby 1982). McCool et al. (1987) suggested an equation of the following form to describe interrill erosion:

$$
E=a \operatorname{Sin}^{b} \theta+c
$$

where $\theta$ is the slope angle in degrees and $a, b$, and $c$ are fitted constants. Although equations (1) and (2) indicate that erosion continues to increase as slope increases, laboratory research by Foster and Martin (1969) found that erosion increases with slope angle up to a point, after which erosion decreases with further increases in slope. On undisturbed rangelands in Idaho, Renner (1936) found that site erodibility was no longer affected by slope changes after slope gradients exceeded $70 \%$. The effect of slope on erosion should not be as great on undisturbed forest and rangelands as on cultivated lands, mine spoils, or construction sites. Besides the positive effect of vegetal cover, the greater surface roughness of undisturbed sites reduces the velocity of overland flow (Schumm 1962, Emmett 1970). Also, rilling is not common on undisturbed areas (Emmett 1978). Lattanzi et al. (1974) reasoned that rill erosion is more strongly influenced by slope than is interrill erosion.

A significant percentage of semiarid rangelands has slope gradients $>25 \%$, yet few studies evaluating interrill erosion on rangelands have included slopes $>10 \%$, thus the impact of slope gradient to interrill erosion has been little evaluated. One obvious reason for this is the difficulty of simulating rainfall on steep slopes. The objective of this research was to evaluate the relative influence of vegetation and soil factors, rock cover, and slope gradient on interrill erosion of semiarid rangeland with slope gradients up to $70 \%$. Included within the above objective was to determine whether the relative influence of the evaluated factor changed within a given rainfall event.

\section{Study Area and Methods}

The study area was in the northern Guadalupe Mountains of New Mexico. Average annual precipitation is about $500 \mathrm{~mm}$. Soils are shallow $(100-500 \mathrm{~mm})$ and are classified as loamy-skeletal, carbonatic, mesic Lithic Calciustolls (Deama series) or clayey, mixed mesic Lithic Argiustolls (Encierro series) (USDA 1981). Deeper soils occur on alluvial fans and alluvial valleys, and are classified as fine, mixed mesic Aridic Haplustalfs (Montecito series). Vegetation formations are succulent desert and evergreen 
woodland as described by Gehlbach (1967). Part of the study area (1,940 ha) has been grazed since 1947 , primarily by $700-1,300$ sheep during a 3 to 4-month period in the winter. The remainder of the area was grazed yearlong by cattle at a stocking rate of about 2 ha per animal unit. A more detailed description of the study area appears in Wilcox et al. (1988).

Simulated rainfall was applied to 88 small plots, about $1 \mathrm{~m}^{2}$ in size, using a single nozzle rainfall simulator suitable for use on steep slopes, described by Wilcox et al. (1986). Application rate was $103 \mathrm{~mm} \mathrm{~h}^{-1}$. The drop sizes produced by this simulator were smaller than those of a natural rainfall event of the same intensity; thus interrill erosion rates produced were probably lower than interrill erosion rates would be under natural rainfall of similar intensity. These data, however, are applicable for an exploratory study such as this, where the relative impacts of slope, rock, vegetation, and soils to interrill erosion are being evaluated.

Rainfall was simulated on the steep slopes of the Guadalupe Rim (46 plots), a fault scarp with slope gradients generally greater than $30 \%$, and on hillslopes above the Guadalupe Rim (42 plots). Slope gradients above the Guadalupe Rim were generally less than $10 \%$. Because of this discontinuity of slope gradient, intermediate gradients (17-30\%) could not be sampled.

Rainfall was initially applied to each plot for $45 \mathrm{~min}$ on dry soil (dry run). This was followed a day later with a 35-min application (wet run). Each plot was covered with plastic immediately after the dry run to reduce evaporation. Runoff was collected continuously and weighed at 5-min intervals. Three, 1-liter samples were collected beginning at 5,25 , and 45 min during the dry run and 5,20 , and 35 min during the wet run.

The sediment concentration was determined by allowing the sediment in each sample to settle and decanting the water. The remaining water and sediment were placed in petri dishes and dried at $105^{\circ} \mathrm{C}$ for $24 \mathrm{~h}$. Sediment concentration of each sample was expressed as $\mathrm{g} \Gamma^{1}$. Interrill erosion on each plot was calculated as

$$
E=\left(C_{1} R_{1}+C_{2} R_{2}+C_{8} R_{8}\right) / P
$$

where

$$
\begin{aligned}
& \mathbf{E}=\text { Total soil loss from plot }\left(\mathrm{kg} \mathrm{ha}^{-1}\right) \\
& \mathrm{C}_{1}=\text { Sediment concentration }(\mathrm{SC}) \text { at } 5 \mathrm{~min}\left(\mathrm{~kg} I^{-1}\right) \\
& \mathrm{C}_{2}=(5 \mathrm{~min} \mathrm{SC}+25 \mathrm{~min} \mathrm{SC}) / 2\left(\mathrm{~kg} I^{1}\right) \\
& \mathrm{C}_{3}=(25 \mathrm{~min} \mathrm{SC}+45 \mathrm{~min} \mathrm{SC}) / 2\left(\mathrm{~kg} I^{-1}\right) \\
& \mathbf{R}_{1}=\text { total runoff }(l) \text { for first } 5 \mathrm{~min} \\
& \mathbf{R}_{2}=\text { total runoff }(l) \text { from } 5-25 \mathrm{~min} \\
& \mathbf{R}_{3}=\text { total runoff }(l) \text { from } 25-45 \mathrm{~min} \\
& \mathbf{P}=\text { plot size (ha) }
\end{aligned}
$$

Aerial cover of the vegetation was estimated by species using a point sampling method. Only one hit per pin was recorded. One hundred points were read per plot using a $1-\mathrm{m}$ wide point frame with 20 pins. Basal cover of the vegetation was estimated similarly after the vegetation was clipped. Bare ground and rock cover were also noted. Rocks were recorded by size class $(2-12,13-25,26-75$, $76-150,>150 \mathrm{~mm}$ ). Rock cover was estimated before and after the vegetation was clipped. Unless otherwise specified, rock cover as used in this paper refers to cover of rock measured before the vegetation was clipped. Shrubs, grasses, and forbs were each clipped to a $15 \mathrm{~mm}$ height. Plant litter was also collected. The plant material was dried for 48 hours at $60-70^{\circ} \mathrm{C}$ and weighed to determine biomass.

Antecedent soil moisture was estimated for the surface $50 \mathrm{~mm}$ by the gravimetric method (Gardner 1965) using samples collected adjacent to the runoff plot before the first rain application. Soil moisture prior to the wet run was assumed to be approximately at field capacity for all plot locations and thus was not determined. After the wet run, soil samples were collected within the plot at depths of 0-50 mm and 50-100 $\mathrm{mm}$ for particle size analysis and organic carbon analysis. Particle size distribution was determined using the hydrometer method (Bouyoucos 1962). Organic carbon percentage was determined by the Walkley-Black method (Allison 1965). Intact soil cores were used for bulk density determinations (Blake 1965). Slope gradient for each plot was measured as the difference in soil surface elevation between the top and bottom of

\begin{tabular}{|c|c|c|c|c|}
\hline \multirow[b]{2}{*}{ Variable } & \multicolumn{2}{|c|}{ Low slopes (0-17\%) } & \multicolumn{2}{|c|}{ Steep slopes $(30-70 \%)^{b}$} \\
\hline & $\boldsymbol{X}$ & SD & $\boldsymbol{X}$ & SD \\
\hline Slope gradient (\%) & 5.7 & 4.5 & 51.1 & 8.0 \\
\hline Rock cover $2-13$ mm (\%) & 4.2 & 4.5 & 6.5 & 4.8 \\
\hline Rock cover $13-25 \mathrm{~mm}$ (\%) & 4.1 & 4.6 & 7.8 & 4.4 \\
\hline Rock cover $25-75 \mathrm{~mm}(\%)$ & 4.1 & 4.9 & 12.2 & 6.9 \\
\hline $\begin{array}{l}\text { Rock cover } \\
75-150 \mathrm{~mm}(\%)\end{array}$ & 1.4 & 1.8 & 6.1 & 4.6 \\
\hline Rock cover $150+\mathrm{mm}(\%)$ & 0.1 & 0.6 & 1.9 & 2.7 \\
\hline Forb cover (\%) & 1.8 & 2.5 & 1.4 & 1.6 \\
\hline Grass cover (\%) & 38.8 & 15.1 & 24.0 & 13.4 \\
\hline Shrub cover (\%) & 10.0 & 17.1 & 10.7 & 16.9 \\
\hline Litter cover (\%) & 12.9 & 10.2 & 6.2 & 4.7 \\
\hline Grass cover ( $\left.\mathrm{kg} \mathrm{ha}^{-1}\right)$ & 758 & 431 & 875 & 343 \\
\hline Litter biomass ( $\mathrm{kg} \mathrm{ha}^{-1}$ ) & 1337 & 2386 & 647 & 1067 \\
\hline Shrub biomass $\left(\mathrm{kg} \mathrm{ha}^{-1}\right)$ & 1648 & 4139 & 2844 & 5752 \\
\hline Forb biomass $\left(\mathrm{kg} \mathrm{ha}^{-1}\right)$ & 77 & 128 & 67 & 75 \\
\hline Rock cover (\%) & 14.0 & 14.3 & 34.5 & 14.4 \\
\hline \multicolumn{5}{|l|}{ Organic carbon } \\
\hline $0-50$ & 5.3 & 2.0 & 5.3 & 1. \\
\hline \multicolumn{5}{|l|}{ Organic carbon } \\
\hline $50-100 \mathrm{~mm}(\%)$ & 5.8 & 2.3 & 5.3 & 1.2 \\
\hline Bulk density ( $\mathrm{mg} \mathrm{m}^{-3}$ ) & 0.98 & 0.2 & 0.98 & 0.1 \\
\hline Sand 0-50 $\mathrm{mm}(\%)$ & 22.0 & 3.7 & 23.1 & 4. \\
\hline Sand 50-100 mm (\%) & 19.7 & 2.5 & 20.0 & 3.4 \\
\hline Clay 0-50 mm (\%) & 33.5 & 6.5 & 35.3 & 4.8 \\
\hline Clay $50-100 \mathrm{~mm}(\%)$ & 37.1 & 8.0 & 37.3 & 5.4 \\
\hline Soil depth (mm) & 349 & 213 & 265 & 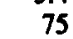 \\
\hline
\end{tabular}
the plot, divided by plot length.

Data were analyzed using Pearson and partial correlation techniques and multiple linear regression. Dependent variables were interrill erosion and sediment concentration. The independent variables appear in Table 1 . The interrill erosion and sediment concentration data were log-transformed to meet the assumption of

Table 1. Mean values ( $\bar{x})$, and associated standard deviations (SD) for measured plot characteristics, Guadalupe Rim, New Mexico.'

Slopes above the Guadalupe Rim fault scarp.

'Slopes on the Guadalupe Rime fault scarp.

dependent variables being normally distributed (Steel and Torrie 1980). Partial correlation analysis was used to account for data multicollinearity (Thorndike 1976). Using this technique, the linear correlations between one or more variables and another pair of variables can be removed. In this way causal relationships can be more confidently inferred. All the variables were related to interrill erosion and sediment concentration as

$$
\log E=b+a X
$$

where $E(\mathbf{k g} / \mathrm{ha})$ is interrill erosion or sediment concentration $(\mathrm{kg} / \mathrm{l}), \mathrm{X}$ is the independent variable, and $\mathrm{a}$ and $\mathrm{b}$ are fitted parameters. Slope was also related to $E$ using equations (1) and (2). Equation (4), however, resulted in as good or a better fit. Results pertaining to equations (1) and (2) are not presented because they were no more illuminating than results from equation (4).

Multiple linear regression models were developed using stepwise regression procedures. The appropriateness of these models was evaluated by residual plotting (Neter et al. 1983). No curvilinearity was detected. Plots from which no runoff occurred were excluded from these analyses. 


\section{Results and Discussion}

Interrill erosion and sediment concentration were well correlated with slope gradient. Correlation coefficients relating sediment concentrations to slope were around .80 for all 3 sampling times during the dry and wet runs. Interrill erosion was slightly less correlated with slope (dry run $r=.6$, wet run $r=.73$ ) (Fig. 1).

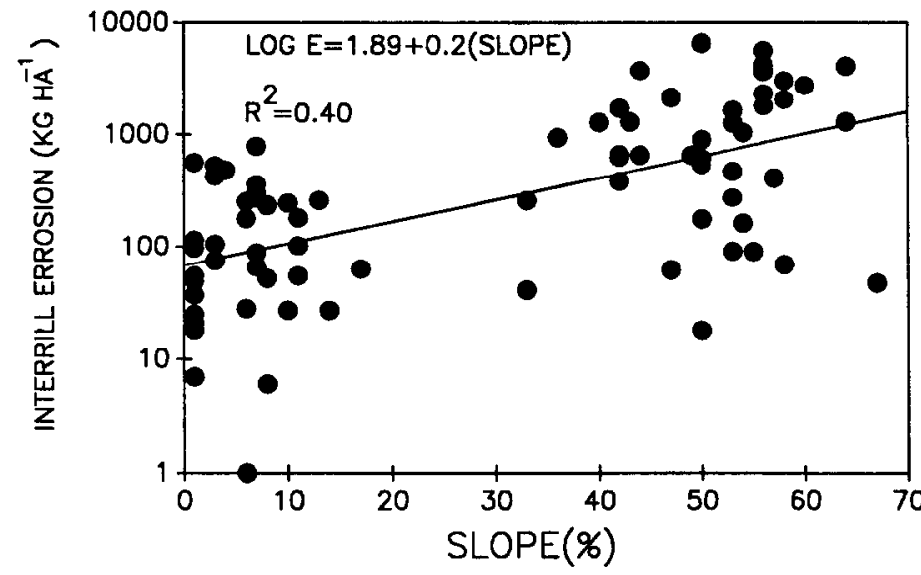

Fig. 1. Relationship of interrill erosion (dry run) and slope gradient, Guadalupe Rim, New Mexico. The line represents values estimated from eq. (4).

Slope gradient was well correlated with vegetal cover (aerial and basal) and rock cover. To remove the effect of these variables on the correlation between interrill erosion and slope gradient partial correlation analysis was used (Table 2). Coefficients were greatest during the wet run, suggesting that slope has a greater impact on interrill erosion and sediment concentration as the soil becomes wetter.

Interrill erosion is a production of both runoff and sediment concentration. Slope has little influence on total runoff (Wilcox et al. 1988); thus, the strong positive relationships between slope and interrill erosion is due solely to higher sediment concentration of runoff from the steeper slopes.

Interrill erosion and sediment concentration were highly correlated to vegetation. Interpretation however, was difficult because of intercorrelations between vegetation, rock cover, and slope; thus, the effect of rock cover and slope were removed from the correlations of vegetation factors and the erosion factors (Table 2). One apparent trend elucidated by these data is that vegetal cover has the most impact on interrill erosion and sediment concentrations for dry soils, or at the beginning of runoff when loose fines on the soil surface are most available (Emmett 1978). Shrubs had a greater impact on interrill erosion and sediment concentration than did gasses, forbs, or litter. Note that unlike the other vegetation variables, litter cover was positively associated with sediment concentration. Possibly more loose fines are available on surfaces with a high litter cover. Interrill erosion and sediment concentration were poorly coorelated to basal cover.

Rock cover was measured by size class in an effort to determine the effect of rock size on interrill erosion and sediment concentration. Rock cover is quite high in the Guadalupe Mountains (Table 1). Partial correlation analysis was very useful in discerning the impact of rock cover on interrill erosion. For example, the Pearson correlations relating rock cover to interrill erosion were highly positive, suggesting that rock cover, rather than protecting against interrill erosion, encourages or promotes it. Partial correlation analysis, however, indicates that rock cover does provide some protection against interrill erosion as indicated by the generally negative correlations (Table 2). No trend in the correlation between rock size and sediment concentration is evident from these data.

Soils in the study area were very similar and a broad range in soil characteristics was not encountered (Table 1). For this reason, soil factors were poorly correlated to interrill erosion. Significant correlation did occur for those plots sampled on the steep slopes (30-70\%) of the Guadalupe Rim (Table 3). Interrill erosion and sediment concentration were positively correlated with the amount

Table 2. Partial correlation coefifielents between sediment concentration or interrill erosion and vezetation and rock variable of the Guadalupe Rim, New Mexico. Only coeficients denificantly different from $0(P \leq 0.1)$ are listed.

\begin{tabular}{|c|c|c|c|c|c|c|c|c|}
\hline \multirow[b]{3}{*}{ Time (min) } & \multicolumn{6}{|c|}{ Sediment concentration } & \multicolumn{2}{|c|}{ Interrill erosion } \\
\hline & \multicolumn{3}{|c|}{ Dry } & \multicolumn{3}{|c|}{ Wet } & \multirow[b]{2}{*}{ Dry } & \multirow[b]{2}{*}{ Wet } \\
\hline & 5 & 25 & 45 & 5 & 20 & 35 & & \\
\hline \multirow[t]{2}{*}{ Variable } & \multicolumn{8}{|c|}{ Slope gradient } \\
\hline & \multicolumn{8}{|c|}{ Effect of rock cover, vegetal cover and basal vegetal cover removed } \\
\hline \multirow[t]{3}{*}{ Slope gradient (\%) } & .42 & .44 & .52 & .44 & .64 & .57 & 31 & .53 \\
\hline & \multicolumn{8}{|c|}{ Vegetation } \\
\hline & \multicolumn{8}{|c|}{ Effect of slope gradient and rock cover removed } \\
\hline \multirow{10}{*}{$\begin{array}{l}\text { Total vegetal cover }(\%) \\
\text { Grass cover }(\%) \\
\text { Shrub cover (\%) } \\
\text { Litter cover (\%) } \\
\text { Total vegetal biomass }\left(\mathrm{kg} \mathrm{ha}^{-1}\right) \\
\text { Grass biomass }\left(\mathrm{kg} \mathrm{ha}^{-1}\right) \\
\text { Shrub biomass }\left(\mathrm{kg} \mathrm{ha}^{-1}\right) \\
\text { Litter biomass }\left(\mathrm{kg} \mathrm{ha}^{-1}\right)\end{array}$} & -.40 & -.30 & -.29 & -.24 & NS & -.19 & -.42 & -.34 \\
\hline & NS & NS & NS & NS & NS & NS & NS & NS \\
\hline & -.23 & -.22 & -.27 & -.24 & -.17 & NS & -.31 & -.30 \\
\hline & NS & NS & NS & .16 & .18 & .18 & NS & NS \\
\hline & -.33 & -.28 & -.28 & -.42 & NS & -.16 & -.40 & -.39 \\
\hline & NS & NS & NS & NS & .23 & NS & NS & NS \\
\hline & -.35 & -.28 & -.30 &.- .44 & -.23 & -.25 & -.37 & -.42 \\
\hline & -.16 & -.17 & NS & -.24 & NS & NS & -.30 & -.17 \\
\hline & \multicolumn{8}{|c|}{ Rock cover } \\
\hline & \multicolumn{8}{|c|}{ Effect of slope gradient and vegetal cover removed } \\
\hline Total rock cover $(\%)$ & NS & -.17 & -.20 & -.17 & NS & NS & -.19 & NS \\
\hline 2-12 mm (\%) & .21 & NS & NS & -.28 & -.22 & NS & NS & NS \\
\hline $13-25 \mathrm{~mm}(\%)$ & NS & NS & NS & NS & NS & NS & NS & NS \\
\hline 26-75 mm (\%) & -.17 & -.17 & -.18 & NS & NS & NS & -.26 & NS \\
\hline $76-150 \mathrm{~mm}(\%)$ & NS & NS & NS & NS & .17 & NS & -.16 & NS \\
\hline $150 \mathrm{~mm}(\%)$ & NS & NS & NS & .24 & NS & NS & NS & NS \\
\hline
\end{tabular}


Table 3. Correlation coeficients between soll factors and sediment concentration or interrill erodion for dry and wet runs on the steep slopes (30-70\%) of the Gaudalupe Rim, New Mexico. Only coeficients siznificantly difierent from $0(P<0.1)$ are listed.

\begin{tabular}{|c|c|c|c|c|c|c|c|c|}
\hline \multirow[b]{3}{*}{ Time (min) } & \multicolumn{6}{|c|}{ Sediment concentration } & \multicolumn{2}{|c|}{ Interrill erosion } \\
\hline & \multicolumn{3}{|c|}{ Dry } & \multicolumn{3}{|c|}{ Wet } & \multirow[b]{2}{*}{ Dry } & \multirow[b]{2}{*}{ Wet } \\
\hline & 5 & 25 & 45 & 5 & 20 & 35 & & \\
\hline $\begin{array}{l}\text { Variable } \\
\text { Sand (\%) } \\
\text { Silt }(\%) \\
\text { Clay }(\%) \\
\text { Organic matter }(\%) \\
\text { Bulk density }\left(\mathrm{mg} \mathrm{m}^{-3}\right) \\
\text { Soil depth }(\mathrm{mm})\end{array}$ & $\begin{array}{r}-.37 \\
.61 \\
-.44 \\
\text { NS } \\
\text { NS } \\
.26\end{array}$ & $\begin{array}{c}\text { NS } \\
.42 \\
-.31 \\
\text { NS } \\
\text { NS } \\
.30\end{array}$ & $\begin{array}{r}-.39 \\
.44 \\
\text { NS } \\
\text { NS } \\
\text { NS } \\
\text { NS }\end{array}$ & $\begin{array}{r}-.35 \\
.44 \\
-.26 \\
\text { NS } \\
\text { NS } \\
\text { NS }\end{array}$ & $\begin{array}{r}-.36 \\
.43 \\
\text { NS } \\
\text { NS } \\
\text { NS } \\
.28\end{array}$ & $\begin{array}{r}-.36 \\
.50 \\
-.32 \\
\text { NS } \\
\text { NS } \\
\text { NS }\end{array}$ & $\begin{array}{r}\text { NS } \\
.55 \\
-.36 \\
-.26 \\
\text { NS } \\
\text { NS }\end{array}$ & $\begin{array}{l}\text { NS } \\
.46 \\
\text { NS } \\
\text { NS } \\
\text { NS } \\
\text { NS }\end{array}$ \\
\hline
\end{tabular}

of silt in the top $50 \mathrm{~mm}$ of the soil profile, whereas they were negatively correlated with sand and clay. Wischmeier and Mannering (1969) showed similar results. Sediment concentration of the runoff was higher from deeper soils. The range in soil bulk density was very limited, thus, it was not correlated with interrill erosion or sediment concentration. Organic matter differences had little impact on sediment concentrations as well, probably for the same reason. Organic matter was, however, generally higher than $2 \%$. De Ploy and Poeson (1985) observed that once organic matter surpasses $2 \%$, further increases have little effect on soil erosion. Wischmeier and Mannering (1969), however, indicated that erosion is negatively influenced by organic matter for organic matter contents up to $4 \%$.

Multiple linear regression (MLR) models estimating log-trans-

Table 4. Multiple linear repreasion equations with log trand formed (base e) interrill erodion or sediment concentration (dry run) as the dependent variables, Guadalupe Rim, New Mexico.

\begin{tabular}{|c|c|c|c|c|}
\hline Variable & $\begin{array}{l}\text { Partial } \\
\text { regression } \\
\text { coefficient }\end{array}$ & F-value & $\mathbf{R}^{2}$ & $\mathbf{N}$ \\
\hline \multirow{8}{*}{$\begin{array}{l}\text { Intercept } \\
2-13 \mathrm{~mm} \text { rock cover } \\
(\%)^{\circ} \\
\text { Slope gradient }(\%) \\
\text { Litter biomass }\left(\mathrm{kg} \mathrm{ha}^{-1}\right) \\
\text { Silt } 0-50 \mathrm{~mm}(\%) \\
\text { Soil moisture } \\
0-50 \mathrm{~cm}(\%)\end{array}$} & \multicolumn{3}{|c|}{ Interrill erosion ( $\mathrm{kg} / \mathrm{ha})$} & \multirow{8}{*}{7} \\
\hline & \multirow{5}{*}{$\begin{array}{c}0.064 \\
0.055 \\
-0.0005 \\
0.058\end{array}$} & \multirow[t]{2}{*}{0.446} & \multirow{7}{*}{.71} & \\
\hline & & & & \\
\hline & & 4.59 & & \\
\hline & & $\begin{array}{l}95.44 \\
19.52\end{array}$ & & \\
\hline & & 8.76 & & \\
\hline & & & & \\
\hline & 0.077 & 12.29 & & \\
\hline \multirow{6}{*}{$\begin{array}{l}\text { Intercept } \\
\text { 13-25 mm rock cover } \\
\quad(\%)^{b} \\
\text { Slope gradient }(\%) \\
\text { Shrub biomass }\left(\mathrm{kg} \mathrm{ha}^{-1}\right) \\
\text { Silt 0-50 mm (\%) } \\
\text { Soil moisture (\%) }\end{array}$} & \multicolumn{3}{|c|}{ 5-min sediment concentration $(\mathrm{g} / \mathrm{l})$} & \multirow{6}{*}{68} \\
\hline & \multirow{5}{*}{$\begin{array}{c}0.054 \\
0.050 \\
-0.0001 \\
0.053 \\
0.033\end{array}$} & -3.464 & \multirow{5}{*}{.80} & \\
\hline & & 7.68 & & \\
\hline & & 126.49 & & \\
\hline & & $\begin{array}{r}7.47 \\
15.69\end{array}$ & & \\
\hline & & 5.58 & & \\
\hline \multirow{6}{*}{$\begin{array}{l}\text { Intercept } \\
\text { Slope gradient (\%) } \\
\text { Grass biomass }\left(\mathrm{kg} \mathrm{ha}^{-1}\right) \\
\text { Shrub biomass }\left(\mathrm{kg} \mathrm{ha}^{-1}\right) \\
\text { Silt 0-50 mm (\%) } \\
\text { Total rock cover }(\%)^{\mathbf{a}}\end{array}$} & \multicolumn{3}{|c|}{ 25-min sediment concentration $(\mathrm{g} / \mathrm{l})$} & \multirow{6}{*}{69} \\
\hline & -2.200 & & & \\
\hline & 0.058 & 105.54 & .71 & \\
\hline & -0.0005 & 4.88 & & \\
\hline & $\begin{array}{c}-0.0001 \\
0.045\end{array}$ & $\begin{array}{r}18.35 \\
9.50\end{array}$ & & \\
\hline & -0.021 & 7.92 & & \\
\hline & \multicolumn{3}{|c|}{ 45-min sediment concentration $(\mathrm{g} /)$} & \multirow[b]{2}{*}{.73} \\
\hline $\begin{array}{l}\text { Intercept } \\
\text { Slope gradient (\%) } \\
\text { Sand } 50-100 \mathrm{~mm}(\%)\end{array}$ & $\begin{array}{c}0.150 \\
0.040 \\
-0.063\end{array}$ & $\begin{array}{r}135.91 \\
6.05\end{array}$ & .67 & \\
\hline
\end{tabular}

\footnotetext{
Rock cover measured before vegetation clipped.
}

Rock cover measured after vegetation clipped.

N-sample number. formed interrill erosion and sediment concentration were developed for dry and wet runs. Only the dry-run models are presented here because of similarity of the results (Table 4). Coefficients of determination $\left(R^{2}\right)$ were slightly higher for the dry-run models. Slope gradient, as evidenced by the high associated $F$ values, accounted for most of the variation in both the interrill erosion and sediment concentration models. Other variables included were components of vegetal biomass (litter, shrub, grass), rock cover, and soil textural class. These models indicate (assuming other variables remain constant) that vegetation, total rock cover, and sand content have a negative impact on interrill erosion and sediment concentration, while slope gradient, silt content, antecedent soil moisture, and 2-25 mm-sized rock fragments are positively related to interrill erosion and sediment concentration.

Application of the MLR equations illustrate that vegetation (in this case, litter biomass) can greatly reduce interrill erosion on steep slopes (Fig. 2). As vegetation increases, the impact of slope on

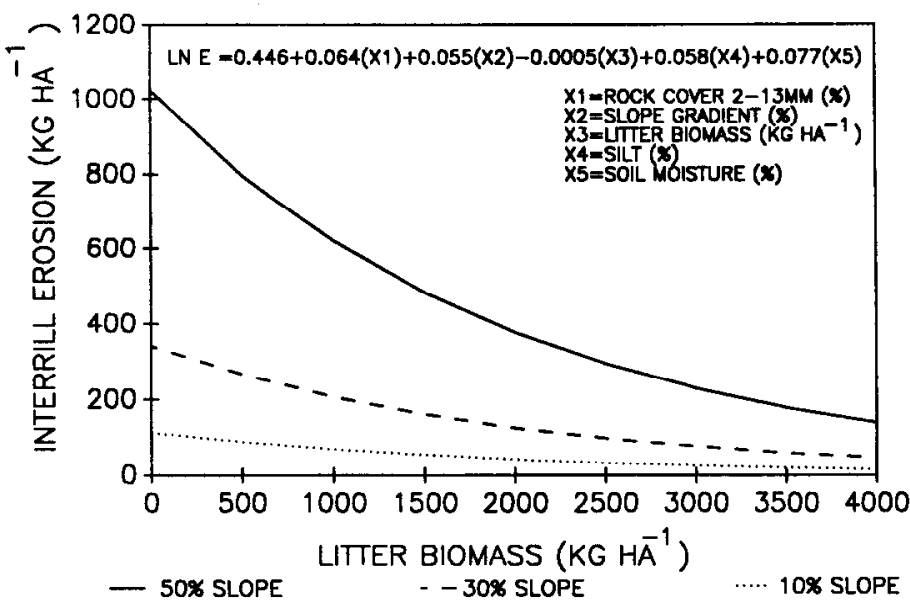

Fig. 2. Interrill erosion (dry run), Guadalupe Rim, New Mexico, predicted from the multiple linear regression equation where average observed values were used for silt, rock cover, and antecedent moisture. The range of values used for litter biomass was within the range encountered in the field.

erosion decreases; the steeper the slope, the more sensitive erosion is to changes in vegetation. Lattanzi et al. (1974) and Meewig and Packer (1976) also concluded that vegetation can counter the effect of slope. Figure 1 also supports this conclusion. For example, the general increase in interrill erosion with slope gradient is evident, but there is also wide data scatter. Interrill erosion (dry run) on slopes of $50 \%$ gradient varied from 30 to $8,000 \mathrm{~kg} \mathrm{ha}^{-1}$. Lowest interrill erosion occurred where infiltration rates were higher and runoff began late into the simulation event. It is the considerable scatter of the data that suggests to one that the effect of slope can be muted by other factors that encourage infiltration. 


\section{Conclusions}

The objective of this study was to determine the relative impact of slope, vegetation, rock cover, and soil on interrill erosion from steep semiarid slopes. Results indicate that factors shown by other studies to influence interrill erosion on moderately sloping rangeland are important on steep slopes, but when a wide range in slope gradient is evaluated, slope gradient is the major factor influencing interrill erosion on semiarid rangelands. This study indicates the following about interrill erosion from semiarid slopes.

1. Slope gradient has a large positive impact on interrill erosion because sediment concentration (not runoff) is greater from steep slopes. Data also indicate, however, that the effect of slope can be greatly muted by vegetation. Interrill erosion is more affected by slope gradient when soil moisture is high.

2. Interrill erosion is negatively correlated to vegetal cover and biomass. The greatest impact of vegetation on interrill erosion occurs during the beginning of runoff, particularly for dry antecedent soil conditions. Basal cover of the vegetation gives a poor index of the protection to the soil surface provided by vegetation.

3. Interrill erosion is higher from rock covered surfaces than from well-vegetated areas. Rock cover, however, does afford some protection against interrill erosion. Rock size has little bearing on interrill erosion.

\section{Literature Cited}

Allison, L.E. 1965. Organic carbon. p. 1367-1378. In: C.A. Black (ed.). Methods of soil analysis. No. 9 Monogr. Ser., Part I., Amer. Soc. Agron., Madison, Wisc.

Blake, G.R. 1965. Bulk density. p. 374-390. In. C.A. Black (ed.), Methods of soil analysis. No. 9 Monogr. Ser., Part I., Amer. Soc. Agron., Madison, Wisc.

Bouyoucos, G.J. 1962. Hydrometer method improved for making particle size analysis of soil. Agron. J. 54:464-465.

Branson, F.A., G.F. Gifford, K.G. Renard, and R.F. Hadley. 1981. Rangeland hydrology. Kendall Hunt Pub. Co., Dubuque, Iowa.

Carson, M.A., and M.J. Kirkby. 1972. Hillslope form and process. Cambridge Univ. Press, N.Y.

Craddock, G.W., and C.K. Pearse. 1938. Surface runoff and erosion on granitic mountain soils of Idaho as influenced by range cover, soil disturbance, slope, and precipitation intensity. USDA Circ. 482.

De Ploey, J., and J. Poesen. 1985. Aggregate stability, runoff generation and interrill erosion. In: K.S. Richards, R.R. Arnett, and S. Ellis (eds.). Geomorphology and soils. George Allen, London.

Emmett, W.M. 1970. The hydraulics of overland flow on hillslopes. USGS Prof. Pap. 662-A.

Emmett, W.M. 1978. Overland flow. p. 145-147. In: M.J. Kirby (ed.), Hillslope hydrology. John Wiley and Sons, N.Y.
Foater, R.L., and G.L. Martin. 1969. Effects of unit weight and slope on erosion. Irrig. and Drain. Div., Amer. Soc. Civ. Eng. 95:551-561.

Gardner, W.H. 1965. Water content, p. 82-125. In: C.A. Black (ed.). Methods of soil analysis. No. 9 Monogr. Ser., Part I., Amer. Soc. Agron., Madison, Wisc.

Gehlbach, F.R. 1967. Vegetation of the Guadalupe Escarpment, New Mexico-Texas. Ecol. 48:404-419.

Hadley, R.F., and S.A. Schumm. 1961. Hydrology of the Upper Cheyenne river basin. B. sediment sources and drainage-basin characteristics in Upper Cheyenne river basin. USGS Water-Supply Pap. 1531.

Lattand, A.R., L.D. Meyer, and M.F. Baumgardner. 1974. Influences of mulch rate and slope steepness on interrill erosion. Soil Sci. Soc. Amer. Proc. 38:946-950.

Leopold, L.B., W.W. Emmett, and R.M. Myrick. 1966. Channel and hillslope processes in a semiarid area, New Mexico. USGS Prof. Pap. 352-G.

McCool, D.K., L.C. Brown, G.R. Foater, C.K. Mutchler, and L.D. Meyer. 1987. Revised slope steepness factors for the Universal Soil Loss Equation. Trans. Amer. Soc. Agr. Eng. 30:1387-1396.

Meeuwic, R.O. 1970. Infiltration and soil erosion as influenced by vegetation and soil in northern Utah. J. Range Manage. 33:185-188.

Meeuwig, R.O., and P. Packer. 1976. Erosion and runoff from forest and rangelands. p. 105-1 16. In: H.F. Heady (ed.). Watershed management on range and forest lands. Utah Water Reserch Lab., Utah State Univ., Logan, Utah.

Neter, J., W. Wasaerman, and M.H. Kutner. 1983. Applied linear regression models. Richard D. Irwin Inc., Homewood, Ill.

Renner, F.G. 1936. Conditions influencing erosion on the Boise River Watershed. USDA Tech. Bull. 528.

Schumm, S.A. 1962. Erosion on miniature pediments in Badlands National Monument, South Dakota. Geol. Soc. Amer. Bull. 73:719-724.

Schumm, S.A. 1977. The fluvial system. John Wiley and Sons, N.Y.

Selby, M.J. 1982. Hillslope materials and processes. Oxford Univ. Press, Oxford.

Simanton, J.R., E. Rawitz, and E.D. Shirley. 1984. Effects of rock fragments on erosion of semiarid rangeland soils. p. 65-72. In: Soil Sci. Soc. Amer. Spec. Pub. 13.

Steel, R.G.D., and J.H. Torrie. 1980. Principles and procedures of statistics, a biometrical approach. McGraw-Hill, N.Y.

Thorndike, R.M. 1976. Correlational procedures for research. Gardner Press Inc., N.Y.

USDA. 1981. Soil survey of Otero area, New Mexico, parts of Otero, Eddy and Chavez Counties. USDA, Soil Conserver. Serv., Forest Serv., and New Mexico Agr. Exp. Sta.

Wilcox, B.P., M.K. Wood, and J.M. Tromble. 1988. Factors influencing infiltrability of semiarid slopes. J. Range Manage. 41:197-206.

Wilcox, B.P., M.K. Wood, J.M. Tromble, and T.J. Ward. 1986. A handportable single nozzle rainfall simulator designed for use on steep slopes. J. Range Manage. 39:375-377.

Wischmeier, W.H., and J.V. Mannering. 1969. Relation of soil properties to its erodibility. Soil Sci. Soc. Amer. Proc. 33:131-137.

Young, R.A., and C.A. Onstad. 1982. The effect of soil characteristics on erosion and nutrient loss. Int. Assoc. Hydrol. Pub. 137-105-113.

Zinge, A.W. 1940. Degree and length of land slope as it affects soil loss in runoff. Agr. Eng. 21:59-64. 